\title{
Influence of Organic Loading Rate on the Performance of a Two-Phase Pressurized Biofilm (TPPB) System Treating Food Waste
}

\author{
Yeqing Li ${ }^{1}$ *, Fang Yan', Hong Liu', ${ }^{1,}$, Yafei Wang1, Hong Nie ${ }^{3}$, \\ Hao Jiang', Mingyu Qian", ${ }^{1,}$ Hongjun Zhou ${ }^{1}$ \\ 'Institute of New Energy, State Key Laboratory of Heavy Oil Processing, \\ Beijing Key Laboratory of Biogas Upgrading Utilization, China University of Petroleum Beijing (CUPB), \\ Beijing, P. R. China, 102249 \\ ${ }^{2}$ Beijing Jeegreen Technology Development Co., Ltd., Beijing, P. R. China, 102200 \\ ${ }^{3}$ Institute of Agricultural Applied Microbiology, Jiangxi Academy of Agricultural Sciences, \\ Nanchang, P. R. China, 330200 \\ ${ }^{4}$ Faculty of Agricultural and Environmental Sciences, University of Rostock, \\ Justus-von-Liebig-Weg 6, 18059 Rostock, Germany
}

Received: 27 December 2016

Accepted: 9 March 2017

\begin{abstract}
A two-phase pressurized biofilm (TPPB) system, including a continuously stirred tank reactor (CSTR) and a pressurized biofilm anaerobic reactor (PBAR), was used to produce high calorific biogas without additional upgrading equipment. The influence of organic loading rate (OLR) on biogas and methane production performance was investigated. Three different OLR levels $(4,5$, and $6 \mathrm{~g}$-COD/L/d) were applied to the PBAR in sequence. The headspace pressure of PBAR was controlled at 1.0 MPa. Biogas production, gas composition, and process stability parameters were measured. Results found that the highest methane yield of $332.8 \mathrm{~mL} / \mathrm{g}$-COD was obtained at OLR of $5 \mathrm{~g}-\mathrm{COD} / \mathrm{L} / \mathrm{d}$. As compared to approximately $90 \%$ methane concentration at OLR of $3.1 \mathrm{~g}-\mathrm{COD} / \mathrm{L} / \mathrm{d}$, the methane content in produced biogas was only $76 \%$ at OLR of $5.0 \mathrm{~g}-\mathrm{COD} / \mathrm{L} / \mathrm{d}$. The $\mathrm{pH}$ value in the pressurized reactor has an important impact on the quality of produced biogas. Further study should focus on the solution strategies of maintaining suitable $\mathrm{pH}$ under higher pressure and higher OLR.
\end{abstract}

Keywords: anaerobic digestion, organic loading rate, pressure, TPPB system, food waste

\section{Introduction}

In China approximately 90 million tons of food waste (FW) is generated annually [1]. For restaurant waste (RW)

*e-mail: liyeqing@cup.edu.cn, liyeqingcup@126.com specifically, the average daily RW production of China's urban population is $0.10-0.15 \mathrm{~kg} / \mathrm{d}$. China's total national production of RW was estimated to reach 40 million tons per year (0.11 million tons per day). Until now, there are 118 RW treatment facilities (including facilities under construction and planning facilities) in Chinese cities, with a processing capacity of 20,000 tons per day. This means 
that more than $80 \%$ of the generated RW cannot be treated effectively. According to the 13th five-year plan, by 2020 the processing capacity of RW will be up to 36,000 tons per day (equivalent to $30 \%$ of daily RW production). RW in particular is a problematic issue in today's China.

Anaerobic digestion (AD) has been recognized as an environmentally friendly and economic solution for the treatment of organic waste. In the AD process, organic substrate is broken down in an anaerobic condition to produce biogas, the composition of which mainly consists of methane (50-65\%) and carbon dioxide (35-50\%). As compared to landfilling, incineration, and composting, AD was the most environmentally friendly way to dispose of FW [2].

Biogas produced from $\mathrm{AD}$ can be used to produce heat and power, and grid/vehicle-quality natural gas (bionatural gas) after upgrading. For a small-scale AD plant (biogas flows lower than $2,000 \mathrm{~m}^{3} / \mathrm{d}$ ), the upgrading equipment for biogas is either not available or not costeffective. In 2011, an autogenerative high-pressure digestion (AHPD) reactor was described to upgraded biogas without additional upgrading equipment, where high $\mathrm{CH}_{4}$ content of $90 \%$ at a pressure of $0.3-9.0 \mathrm{MPa}$ was obtained [3]. Chen et al. [4] further developed a two-phase pressurized anaerobic digestion (TPPAD) system to convert maize/grass silage into high-quality biogas $\left(\mathrm{CH}_{4}>75 \%\right)$. Our previous study found that at an organic loading rate (OLR) of $3.1 \mathrm{~g}-\mathrm{COD} / \mathrm{L} / \mathrm{d}$, highcalorific biogas (higher calorific value of produced biogas was $36.2 \mathrm{MJ} / \mathrm{m}^{3}$ ) was obtained via $\mathrm{AD}$ of food waste by using a two-phase pressurized biofilm (TPPB) system [5]. As OLR is an important parameter for evaluating the efficiency of the AD system, in this study, we will further investigate the effect of organic loading rate on the performance of a two-phase pressurized biofilm (TPPB) system treating food waste. The process stability, biogas, and methane yield, biogas composition, and firstorder reaction rate constant $(k)$ for the semi-continuous pressurized reactor will be discussed.

\section{Materials and Methods}

Substrates and Inoculum

In this study, food waste (FW) was collected from a canteen of China University of Petroleum Beijing (CUPB). The plastic bags, bones, and chopsticks were removed before $\mathrm{FW}$ was crushed to a mean particle size of $3 \mathrm{~mm}$. Then $\mathrm{FW}$ was stored at $4^{\circ} \mathrm{C}$ prior to use. Inoculum used in this study was obtained from a running mesophilic anaerobic reactor digesting various organic wastes in a laboratory of the Institute of New Energy, CUPB. Total solids (TS), VS/TS ratio, and $\mathrm{pH}$ were $22.73 \pm 0.05 \%$, $92.42 \pm 0.06 \%$, and $6.86 \pm 0.06$ for $\mathrm{FW}$, and $1.33 \pm 0.01 \%$, $43.56 \pm 0.96 \%$, and $7.76 \pm 0.01$ for inoculum, respectively $[5]$.

Anaerobic Reactors and Experimental Procedure

The flow diagram of the two-phase pressurized biofilm (TPPB) system is shown in Fig. 1. Hydrolysis-acidification was performed in a CSTR with working volume of 5.0 L. The reactor performed at $37^{\circ} \mathrm{C}$ and the stirring rate was kept at $120 \mathrm{rpm}$. Hydraulic retention time (HRT) of the reactor was maintained at six days. The organic loading rate (OLR) of smashed food waste in the acidogenesis phase was controlled to $5 \mathrm{~g}-\mathrm{VS} / \mathrm{L} / \mathrm{d}$.

For the methanogenesis phase we used a $4.0 \mathrm{~L}$ pressurized biofilm anaerobic reactor (PBAR) with working volume of 3.0 L. Biomedia pellets in PBAR were pre-incubated with inoculum and food waste for microbial enrichment under anaerobic conditions $\left(37^{\circ} \mathrm{C}\right)$. The OLR was increased gradually from $3.1 \mathrm{~g}-\mathrm{COD} / \mathrm{L} / \mathrm{d}$ [5] to 4,5 , and $6 \mathrm{~g}-\mathrm{COD} / \mathrm{L} / \mathrm{d}$. The corresponding HRT was 7, 5, 3.85, and 3.75 days, respectively. The headspace pressure of PBAR was maintained at $1.0 \mathrm{MPa}$.

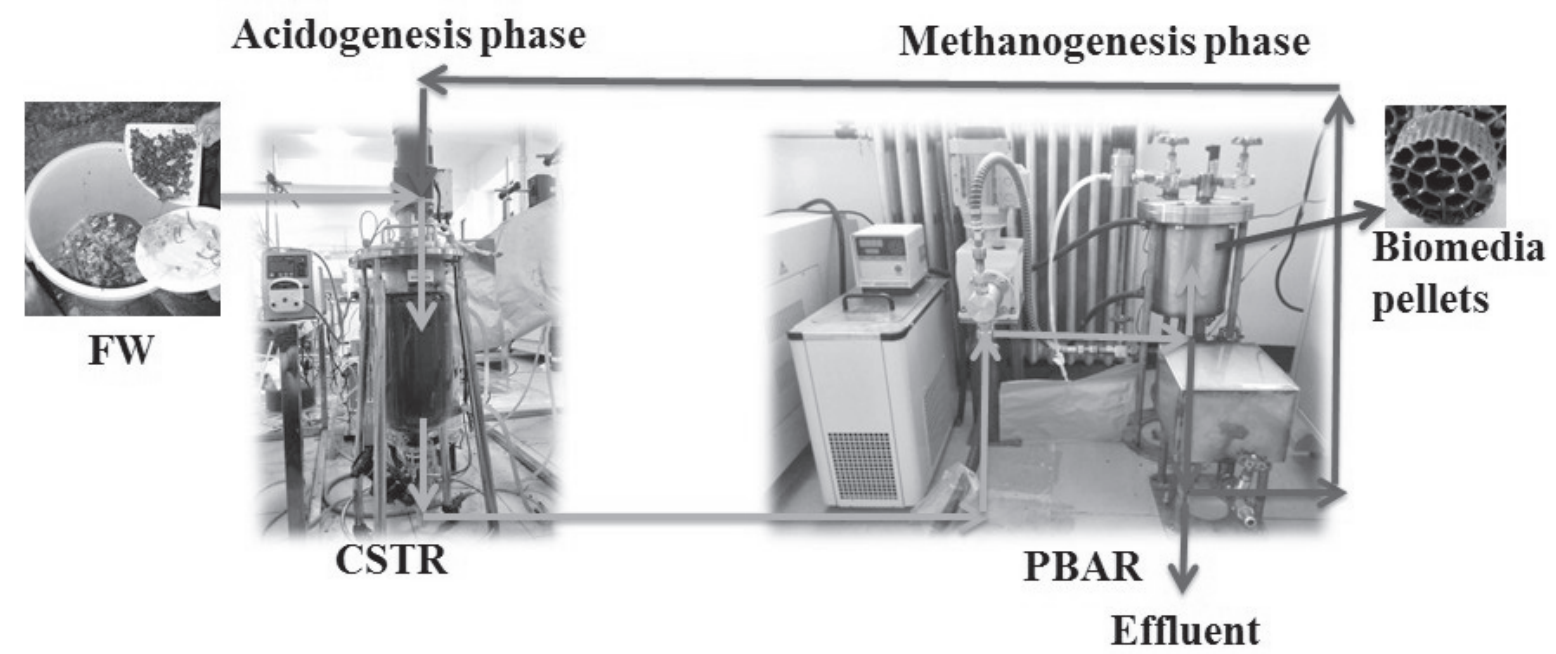

Fig. 1. Flow diagram of the two-phase pressurized biofilm (TPPB) system. 


\section{Analysis Methods}

Biogas samples were taken every two days to measure the gas composition. A gas chromatograph (FULI 9790II, China) equipped with a thermal conductivity detector was used and helium (He) was the carrier gas. The temperature of the injector, oven, and detector were 150, 130, and $160^{\circ} \mathrm{C}$, respectively. Biogas production was determined by a wet gas flow meter (LMF-1, China).

The concentrations of total solids (TS) and volatile solids (VS) were measured according to standard methods [6]. The $\mathrm{pH}$ was determined by using a $\mathrm{pH}$ meter (PB-10, SARTORIUS Company, Germany). Total volatile fatty acids (VFA) and total inorganic carbon (TIC) were detected by using a Mettler Toledo T70 (Switzerland). Chemical oxygen demand (COD) was measured with a $\mathrm{HACH}$ test kit using a COD analyzer (CM-02, SHUANGHUI-JINGCHENG Company, China). Higher calorific values $(\mathrm{HCV})$ and lower calorific values (LCV) of produced biogas were measured according to $\mathrm{Li}$ et al. [5].

\section{Kinetic Model}

A simple model was used in this study to describe the biogas and methane production process [7-8]:

$$
y /\left(y_{m}-y\right)=k \times \mathrm{C}_{0} / \mathrm{OLR}=k \times \mathrm{HRT}
$$

...where $y$ is the methane yield of substrate $(\mathrm{mL}$ $\mathrm{CH}_{4} / \mathrm{g}$-COD), $y_{m}$ is the maximal methane yield of a given substrate $(\mathrm{mL} \mathrm{CH} / \mathrm{g}-\mathrm{COD}), \mathrm{C}_{0}$ is the feeding concentration of substrate $(\mathrm{g}-\mathrm{COD} / \mathrm{L})$, OLR means the organic loading rate $(\mathrm{g}-\mathrm{COD} / \mathrm{L} / \mathrm{d}), k$ stands for the firstorder reaction rate constant $(1 / \mathrm{d})$, and HRT is the hydraulic retention time $(d)$.

\section{Data Analysis}

Single-factor ANOVA was used with significance levels of 0.01 and $0.05(\alpha=0.01$ and 0.05$)$ to determine the significance of differences in the biogas composition, volumetric methane productivity, and biogas and methane production for different operations. Data analysis was determined by SPSS statistics 16.0 (IBM, USA). Graph and data processing were completed by OriginPro 9.0 (OriginLab, USA).

\section{Results and Discussion}

\section{Process Stability in Methanogenesis Phase}

The parameters of $\mathrm{pH}$, VFA, TIC (alkaline buffer capacity), and VFA/TIC ratios in the methanogenesis reactor are shown in Table 1. Under the headspace pressure of 1.0 $\mathrm{MPa}$, with the OLR increasing from $3.1 \mathrm{~g}-\mathrm{COD} / \mathrm{L} / \mathrm{d}$ to $5.0 \mathrm{~g}-\mathrm{COD} / \mathrm{L} / \mathrm{d}$, the $\mathrm{pH}$ value, VFA concentration, and VFA/TIC ratio was found to be 7.05-7.18, $1.27-2.59 \mathrm{~g} / \mathrm{L}$, and $0.14-0.31$, respectively, which were in a suitable range of methane production by anaerobic digestion; when the OLR increased to $6.0 \mathrm{~g}-\mathrm{COD} / \mathrm{L} / \mathrm{d}$, the $\mathrm{pH}$ dropped to $6.84 \pm 0.12$ and the corresponding VFA concentration and VFA/TIC ratio were found to be $3.74 \pm 0.58 \mathrm{~g} / \mathrm{L}$ and $0.47 \pm 0.08$, respectively. According to Li et al. [9], a preferred VFA/TIC ratio under 0.4 was essential and could be used to judge reactor stability. If the ratio of VFA/TIC is less than 0.4, the reactor should be stable. Thus, the PBAR was stable under OLR of $5.0 \mathrm{~g}-\mathrm{COD} / \mathrm{L} / \mathrm{d}$. Based on the finding of Wonneberger et al. [10], the $\mathrm{pH}$ value in a pressurized reactor had the strongest impact on the methane content of the produced gas. A preferred $\mathrm{pH}$ value for $\mathrm{AD}$ ranged from 7.2 to 7.8. The drop in $\mathrm{pH}$ could inhibit the methanogenesis and disrupt the biogas and methane production performance of the anaerobic reactor. Therefore, the methanogenesis reactor showed an unstable trend at OLR of $6.0 \mathrm{~g}-\mathrm{COD} / \mathrm{L} / \mathrm{d}$. Generally speaking, this system can be operated at higher OLR of $5.0 \mathrm{~g}-\mathrm{COD} / \mathrm{L} / \mathrm{d}$ steadily. The corresponding HRT was found to be 3.85 days.

Table 1. Process stability in methanogenesis reactor (standard deviation was obtained based on eight continuous data during steady states).

\begin{tabular}{|c|c|c|c|c|}
\hline & Li et al. (2016) & & This study & \\
\hline OLR (g-COD/L/d) & 3.1 & 4.0 & 5.0 & 6.0 \\
\hline Headspace pressure (MPa) & 1.0 & 1.0 & 1.0 & 1.0 \\
\hline Duration (days) & 15 & 19 & 23 & 3.75 \\
\hline HRT (days) & 7 & 5 & 7.85 & $6.84 \pm 0.12$ \\
\hline pH value & $7.05 \pm 0.05$ & $7.18 \pm 0.08$ & $1.27 \pm 0.71$ & $3.74 \pm 0.58$ \\
\hline VFA (g/L) & $1.50 \pm 0.32$ & $2.59 \pm 0.36$ & $0.14 \pm 0.09$ & $0.47 \pm 0.08$ \\
\hline VFA/TIC ratio & $0.27 \pm 0.07$ & $0.31 \pm 0.04$ & $9.18 \pm 0.71$ & $7.87 \pm 0.43$ \\
\hline TIC $($ g-CaCO $/ \mathrm{L})$ & $5.72 \pm 0.44$ & $8.48 \pm 0.73$ & & \\
\hline
\end{tabular}




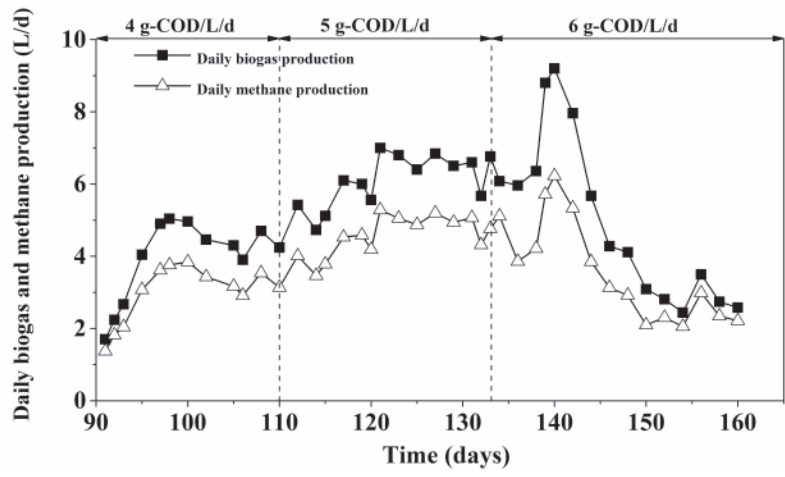

Fig. 2. Daily biogas and methane production in methanogenesis reactor at different OLRs.

Effect of OLR on Biogas and Methane Production

The daily biogas and methane production in the methanogenesis reactor at different organic load rates (OLR) are shown in Fig. 2. With the OLR increasing from $4.0 \mathrm{~g}-\mathrm{COD} / \mathrm{L} / \mathrm{d}$ to $5.0 \mathrm{~g}-\mathrm{COD} / \mathrm{L} / \mathrm{d}$, daily methane production was raised from $3.4 \pm 0.3 \mathrm{~L} / \mathrm{d}$ to $4.9 \pm 0.4 \mathrm{~L} / \mathrm{d}$. When the organic load rate increased to $6.0 \mathrm{~g}-\mathrm{COD} / \mathrm{L} / \mathrm{d}$, daily methane production showed a rising trend and then dropped to $2.7 \pm 0.6 \mathrm{~L} / \mathrm{d}$, indicating that the methanogenesis reactor was unstable at OLR of $6.0 \mathrm{~g}-\mathrm{COD} / \mathrm{L} / \mathrm{d}$. As shown in Table 1, at OLR of $6.0 \mathrm{~g}-\mathrm{COD} / \mathrm{L} / \mathrm{d}$, the $\mathrm{pH}$ value was below 7.0, which also indicated that some inhibition reaction occurred in the methanogenesis reactor. According to Li et al. [5], daily methane production of $2.1 \pm 0.3 \mathrm{~L} / \mathrm{d}$ was found at OLR of $3.1 \mathrm{~g}-\mathrm{COD} / \mathrm{L} / \mathrm{d}$ under the headspace pressure of $1.0 \mathrm{MPa}$. Thus, the highest OLR that can be stable operated was $5.0 \mathrm{~g}-\mathrm{COD} / \mathrm{L} / \mathrm{d}$ with highest daily methane production of $4.9 \pm 0.4 \mathrm{~L} / \mathrm{d}$. Daily biogas production showed the same trend as compared to daily methane production. Highest daily biogas production of $6.6 \pm 0.5 \mathrm{~L} / \mathrm{d}$ was obtained at OLR of $5.0 \mathrm{~g}-\mathrm{COD} / \mathrm{L} / \mathrm{d}$, which was $45 \%$ and $84 \%$ higher than that of at OLR of 4.0 and $6.0 \mathrm{~g}-\mathrm{COD} / \mathrm{L} / \mathrm{d}$, respectively.

\section{Effect of OLR on Biogas Composition}

Biogas composition was influenced by OLR variation (Fig. 3). The methane content decreased from $88.9 \pm 1.3 \%$ to $75.3 \pm 1.4 \%$ as OLR rose from $3.1 \mathrm{~g}-\mathrm{COD} / \mathrm{L} / \mathrm{d}$ to 4.0 $\mathrm{g}-\mathrm{COD} / \mathrm{L} / \mathrm{d}$. At OLR of $5.0 \mathrm{~g}-\mathrm{COD} / \mathrm{L} / \mathrm{d}$ and $6.0 \mathrm{~g}-\mathrm{COD} / \mathrm{L} / \mathrm{d}$, the biogas composition was $75.8 \pm 0.8 \%$ and $77.1 \pm 7.9 \%$, respectively. Similar results were found by Chen et al. [4], where at OLR of $5.1 \mathrm{~g}-\mathrm{COD} / \mathrm{L} / \mathrm{d}$ and pressure of $0.89 \mathrm{MPa}$, the methane content in the methanogenesis reactor was found to be $75 \%$. Lemmer et al. [11] also found that at OLR of $5.0 \mathrm{~g}-\mathrm{COD} / \mathrm{L} / \mathrm{d}$ and pressure of $0.9 \mathrm{MPa}$, methane concentration of $77.3 \%$ was obtained using a mixture of grass and maize silage (G/M-silage) leachate as feedstock. Statistical analysis showed that there was no significant difference among methane content at

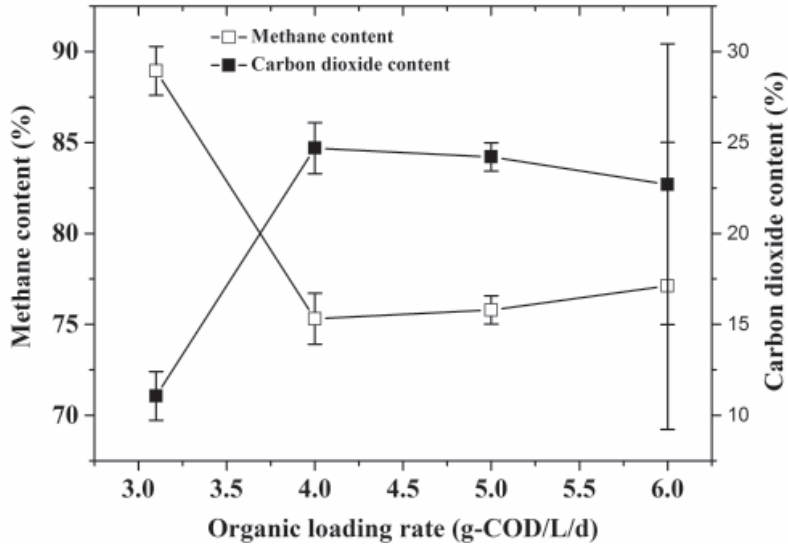

Fig. 3. Biogas composition in methanogenesis reactor under different OLRs.

OLRs of 4.0, 5.0, and $6.0 \mathrm{~g}-\mathrm{COD} / \mathrm{L} / \mathrm{d}$. However, methane content at OLR of $3.1 \mathrm{~g}-\mathrm{COD} / \mathrm{L} / \mathrm{d}$ was significantly higher $(p=0.00<0.01)$ than that of at OLRs of 4.0, 5.0, and $6.0 \mathrm{~g}-\mathrm{COD} / \mathrm{L} / \mathrm{d}$ (Table 2). It is worth noting that at OLR of $6.0 \mathrm{~g}-\mathrm{COD} / \mathrm{L} / \mathrm{d}$, higher error bars of methane and carbon dioxide content were obtained, which also indicated an unstable operation in methanogenesis reactor at this OLR. Besides, $0.4-1.3 \%$ hydrogen was detected in biogas at this stage, indicating that at OLR of $6.0 \mathrm{~g}-\mathrm{COD} / \mathrm{L} / \mathrm{d}$, the activity of methane-producing bacteria was inhibited and the activity of acid-producing bacteria was enhanced.

Usually, the high cost for biogas upgrading is considered a main barrier for further utilization of the $A D$ technology in decentralized appliances [12]. In this study, high calorific biogas was obtained without additional upgrading equipment. According to the calorific value calculation formula [5], lower calorific values (LCV) and higher calorific values (LCV) of produced biogas were in the range of $27.1-27.7 \mathrm{MJ} / \mathrm{m}^{3}$ and $30.1-30.8 \mathrm{MJ} / \mathrm{m}^{3}$ at OLRs of 4.0, 5.0, and $6.0 \mathrm{~g}-\mathrm{COD} / \mathrm{L} / \mathrm{d}$, which is more suitable for direct use as fuel. The $\mathrm{CH}_{4} / \mathrm{CO}_{2}$ ratio in the collected biogas changed from 2.1 to 6.0. The methane was enriched under higher pressure at different OLRs. However, compared to the gas gained with the AHPD technique, methane content of the produced gas in the TPPB system is low [12]. Further study should be done to increase the methane content in the pressurized reactor.

\section{Effect of OLR on Methane Yield and VMP}

Effect of OLR on methane yield (MY) and volumetric methane productivity (VMP) are shown in Fig. 4. With the OLR increasing from $3.1 \mathrm{~g}-\mathrm{COD} / \mathrm{L} / \mathrm{d}$ to 5.0 $\mathrm{g}-\mathrm{COD} / \mathrm{L} / \mathrm{d}$, the MY and VMP increased, which implied that microorganisms gradually adapted higher OLR conditions. Highest MY of $332.8 \pm 24.3 \mathrm{~mL} / \mathrm{g}$-COD and VMP of $1.7 \pm 0.1 \mathrm{~L}_{\text {methane }} / \mathrm{L}_{\text {reactor volume }}$ were obtained at OLR of $5.0 \mathrm{~g}-\mathrm{COD} / \mathrm{L} / \mathrm{d}$, which was $16.9 \%$ and $46.1 \%$, 
Table 2. Statistical analysis on the significant differences in methane content and methane yields of FW at different OLRs (standard deviation was obtained based on eight continuous data during steady states).

\begin{tabular}{|c|c|c|c|c|}
\hline \multicolumn{5}{|c|}{ Methane content } \\
\hline & $3.1 \mathrm{~g}-\mathrm{COD} / \mathrm{L} / \mathrm{d}$ & $4.0 \mathrm{~g}-\mathrm{COD} / \mathrm{L} / \mathrm{d}$ & $5.0 \mathrm{~g}-\mathrm{COD} / \mathrm{L} / \mathrm{d}$ & $6.0 \mathrm{~g}-\mathrm{COD} / \mathrm{L} / \mathrm{d}$ \\
\hline $3.1 \mathrm{~g}-\mathrm{COD} / \mathrm{L} / \mathrm{d}$ & - & V.S. & V.S. & V.S. \\
\hline $4.0 \mathrm{~g}-\mathrm{COD} / \mathrm{L} / \mathrm{d}$ & V.S. & - & N.S. & N.S. \\
\hline $5.0 \mathrm{~g}-\mathrm{COD} / \mathrm{L} / \mathrm{d}$ & V.S. & N.S. & N.S. \\
\hline $6.0 \mathrm{~g}-\mathrm{COD} / \mathrm{L} / \mathrm{d}$ & V.S. & N.S. & - \\
\hline \multicolumn{7}{|c|}{} & Methane yield & V.S. & V.S. \\
\hline $3.1 \mathrm{~g}-\mathrm{COD} / \mathrm{L} / \mathrm{d}$ & - & V.S. & V.S. & V.S. \\
\hline $4.0 \mathrm{~g}-\mathrm{COD} / \mathrm{L} / \mathrm{d}$ & V.S. & V.S. \\
\hline $5.0 \mathrm{~g}-\mathrm{COD} / \mathrm{L} / \mathrm{d}$ & V.S. & V.S. & V.S. & - \\
\hline $6.0 \mathrm{~g}-\mathrm{COD} / \mathrm{L} / \mathrm{d}$ & V.S. & V.S. & \\
\hline
\end{tabular}

S. significant difference, V.S. very significant difference, N.S. no significant difference

and $121.1 \%$ and $84.2 \%$ higher than that of at OLR of 4.0 and $6.0 \mathrm{~g}-\mathrm{COD} / \mathrm{L} / \mathrm{d}$, respectively. Statistical analysis showed that methane yield at OLR of $5.0 \mathrm{~g}-\mathrm{COD} / \mathrm{L} / \mathrm{d}$ was significantly higher $(p<0.01)$ than that of at OLR of 3.1, 4.0, and $6.0 \mathrm{~g}-\mathrm{COD} / \mathrm{L} / \mathrm{d}$. Generally, the optimal OLR in this study was found to be $5.0 \mathrm{~g}-\mathrm{COD} / \mathrm{L} / \mathrm{d}$. A similar result was obtained by Chen et al. [4], where specific methane yield was $310 \mathrm{~mL} / \mathrm{g}-\mathrm{COD}$ at OLR of 5.1 $\mathrm{g}-\mathrm{COD} / \mathrm{L} / \mathrm{d}$ and pressure of $0.89 \mathrm{MPa}$ using maize silage leachate (the COD concentration was $23 \pm 0.9 \mathrm{~g} / \mathrm{L}$ ) from acidogenesis-leach-bed-reactor as feedstock. Further research by Chen et al. [13] showed that their two-phase pressurized anaerobic digestion (TPPAD) system can be run up to OLR of $17.5 \mathrm{~g}-\mathrm{COD} / \mathrm{L} / \mathrm{d}$, achieving the best performance at $12.5 \mathrm{~g}-\mathrm{COD} / \mathrm{L} / \mathrm{d}$ at two working pressures $(0.9$ and $1.5 \mathrm{MPa})$. The lower OLR obtained in this study may be because of the low pH value (approximately 6.8) inside the reactor at higher OLR. Further study should focus on the controlling $\mathrm{pH}$ value in the pressurized reactor.

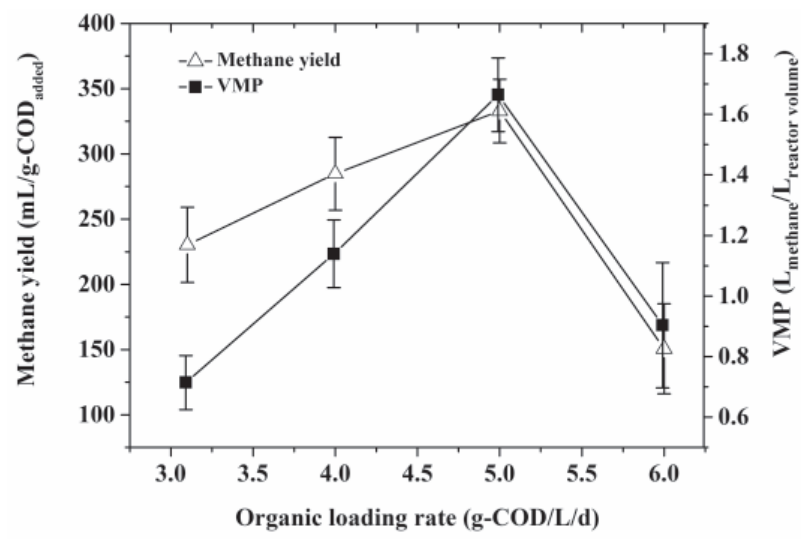

Fig. 4. Effect of OLR on methane yield and volumetric methane productivity.

\section{Effect of OLR on $k$ Value}

There are three main tendencies in anaerobic modelling for predicting reactor behaviour [14]. Based on kinetic equations such as Monod, an unstructured nonsegregated model (UNM) and an unstructured segregated model (USM) are proposed [7]. Firstorder reaction rate constant $(k)$ plays an important role on the evaluation of fermentation efficiency and biodegradability. First-order and cone models are used to determine the $k$ values and to describe the batch anaerobic digestion process [15]. In this study, according to Linke [7], a simple model was used to describe the biogas and methane production process in semi-continuous mode. Methane yield $y$ as a function of maximum methane yield $y_{m}$, reaction rate constant $k$, and HRT are described on the basis of a mass balance in a semi-continuous reactor and a first-order kinetic.

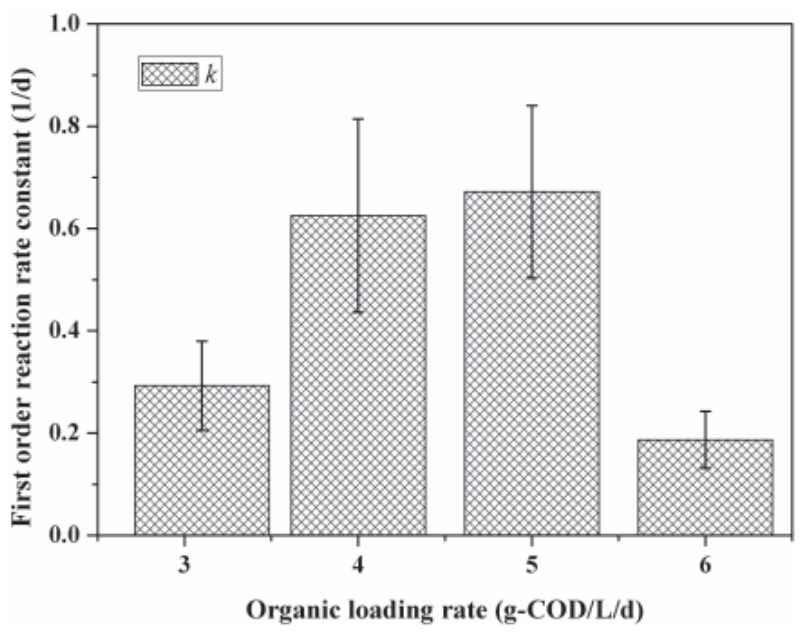

Fig. 5. Effect of OLR on first-order reaction rate constant (k) values. 
According to Eq. (1), first-order reaction rate constant $(k)$ values were calculated at different OLRs. The effect of OLR on $k$ values is shown in Fig. 5 - with OLR increasing from 3.1 to $5.0 \mathrm{~g}-\mathrm{COD} / \mathrm{L} / \mathrm{d}$, the $k$ values increased from $0.29 \pm 0.091 / \mathrm{d}$ to $0.67 \pm 0.171 / \mathrm{d}$, and then dropped to $0.19 \pm 0.061 / \mathrm{d}$ at OLR of $6.0 \mathrm{~g}-\mathrm{COD} / \mathrm{L} / \mathrm{d}$. According to $\mathrm{Li}$ et al. [16], the first-order rate constant $(k)$ for food waste was determined to be $0.181 / \mathrm{d}$ in the batch biochemical methane potential (BMP) test. Higher $k$ value obtained in the current work may be because of the two-phase anaerobic digestion system and higher methane generation efficiency in the pressurized biofilm anaerobic reactor (Fig. 1). In brief, a suitable OLR in a pressurized reactor for methane production was $5.0 \mathrm{~g}-\mathrm{COD} / \mathrm{L} / \mathrm{d}$. The corresponding HRT was found to be 3.85 days (Table 1).

\section{Conclusion}

At OLR of $5.0 \mathrm{~g}-\mathrm{COD} / \mathrm{L} / \mathrm{d}$ and HRT of 3.85 days in a pressurized biofilm anaerobic reactor (PBAR), the TPPB system can operate steadily. Highest methane yield of $332.8 \mathrm{~mL} / \mathrm{g}-\mathrm{COD}$ and volumetric methane productivity of $1.7 \mathrm{~L}_{\text {methane }} / \mathrm{L}_{\text {reactor volume }}$ were obtained at OLR of $5.0 \mathrm{~g}-\mathrm{COD} / \mathrm{L} / \mathrm{d}$, which was $16.9 \%$ and $46.1 \%$, and $121.1 \%$ and $84.2 \%$ higher than that of OLR of 4.0 and $6.0 \mathrm{~g}-\mathrm{COD} / \mathrm{L} / \mathrm{d}$, respectively. The PBAR became unstable at the higher OLR of $6.0 \mathrm{~g}-\mathrm{COD} / \mathrm{L} / \mathrm{d}$ because of the accumulation of VFAs and a decrease in $\mathrm{pH}$. Using higher buffer capacity of leachate as feedstock may be an alternative solution.

\section{Acknowledgements}

This work was supported by the Beijing Municipal Scienceand Technology Project(No.D141100002814001), the National Natural Science Foundation of China (No. 51508572), the Science Foundation of China University of Petroleum, Beijing (No. 2462014YJRC034), and the Coconstruction Project of the Beijing Municipal Education Commission. The authors are grateful for reactor support from the Junlan Group General Corporation.

\section{References}

1. DE CLERCQ D., WEN Z., FAN F., CAICEDO L. Biomethane production potential from restaurant food waste in megacities and project level-bottlenecks: A case study in Beijing. Renew. Sustain. Energ. Rev., 59, 1676, 2016.

2. KHOO H.H., LIM T.Z., TAN R.B. Food waste conversion options in Singapore: environmental impacts based on an LCA perspective. Sci. Total Environ., 408 (6), 1367, 2010.
3. LINDEBOOM R.E.F., FERMOSO F.G., WEIJMA J., ZAGT K., VAN LIER, J.B. Autogenerative high pressure digestion: anaerobic digestion and biogas upgrading in a single step reactor system. Water Sci. Technol., 64 (3), 647, 2011.

4. CHEN Y., ROBLER B., ZIELONKA S., LEMMER A., WONNEBERGER A.M., JUNGBLUTH T. The pressure effects on two-phase anaerobic digestion. Appl. Energ., 116, 409, 2014.

5. LI Y., LIU H., YAN F., SU D., WANG Y., ZHOU H. Highcalorific biogas production from anaerobic digestion of food waste using a two-phase pressurized biofilm (TPPB) system. Bioresour. Technol., 224, 56, 2017.

6. APHA. Standard Methods for the Examination of Water and Wastewater, twenty-first ed. American Public Health Association, Washington, DC, USA, 2005.

7. LINKE B. Kinetic study of thermophilic anaerobic digestion of solid wastes from potato processing. Biomass Bioenerg., 30 (10), 892, 2006.

8. LINKE B., MUHA I., WITTUM G., PlOGSTIES V. Mesophilic anaerobic co-digestion of cow manure and biogas crops in full scale German biogas plants: a model for calculating the effect of hydraulic retention time and VS crop proportion in the mixture on methane yield from digester and from digestate storage at different temperatures. Bioresour. Technol., 130, 689, 2013.

9. LI Y., ZHANG R., HE Y., ZHANG C., LIU X., CHEN C., LIU G. Anaerobic co-digestion of chicken manure and corn stover in batch and continuously stirred tank reactor (CSTR). Bioresour. Technol., 156, 342, 2014.

10. WONNEBERGER A., GRAF F., LEMMER A., CHEN Y., REIMERT R. Modelling and Perspectives of Two-stage Pressurized Fermentation. In: European Biomass Conference and Exhibition Proceedings, 539, 2014.

11. LEMMER A., CHEN Y., LINDNER J., WONNEBERGER A.M., ZIELONKA S., OECHSNER H., JUNGBLUTH T. Influence of different substrates on the performance of a twostage high pressure anaerobic digestion system. Bioresour. Technol., 178, 313, 2015.

12. LINDEBOOM R.E., WEIJMA J., VAN LIER J.B. Highcalorific biogas production by selective $\mathrm{CO} 2$ retention at autogenerated biogas pressures up to 20 bar. Environ. Sci. Technol., 46 (3), 1895, 2012.

13. CHEN Y., ROBLER B., ZIELONKA S., WONNEBERGER A.M., LEMMER A. Effects of organic loading rate on the performance of a pressurized anaerobic filter in two-phase anaerobic digestion. Energies, 7 (2), 736, 2014.

14. GARCIA-OCHOA F., SANTOS V.E., NAVAL L., GUARDIOLA E., LOPEZ B. Kinetic model for anaerobic digestion of livestock manure. Enzyme Microb. Technol., 25 (1), 55, 1999.

15. LI Y., ZHANG R., HE Y., LIU X., CHEN C., LIU G. Thermophilic solid-state anaerobic digestion of alkalinepretreated corn stover. Energ. Fuel., 28 (6), 3759, 2014.

16. LI Y., ZHANG R., LIU G., CHEN C., HE Y., LIU $\mathrm{X}$. Comparison of methane production potential, biodegradability, and kinetics of different organic substrates. Bioresour. Technol., 149, 565, 2013. 